University of Michigan Law School

University of Michigan Law School Scholarship Repository

Law \& Economics Working Papers

$5-12-2019$

\title{
If Not Now, When? US Tax Treaties With Latin America After TCJA
}

Reuven S. Avi-Yonah

University of Michigan Law School, aviyonah@umich.edu

Follow this and additional works at: https://repository.law.umich.edu/law_econ_current

Part of the International Law Commons, Law and Economics Commons, and the Tax Law Commons

Working Paper Citation

Avi-Yonah, Reuven S., "If Not Now, When? US Tax Treaties With Latin America After TCJA" (2019). Law \& Economics Working Papers. 160.

https://repository.law.umich.edu/law_econ_current/160

This Article is brought to you for free and open access by University of Michigan Law School Scholarship Repository. It has been accepted for inclusion in Law \& Economics Working Papers by an authorized administrator of University of Michigan Law School Scholarship Repository. For more information, please contact mlaw.repository@umich.edu. 
DRAFT 5/12/19

\title{
IF NOT NOW, WHEN? \\ Reuven S. Avi-Yonah \\ The University of Michigan
}

US TAX TREATIES WITH LATIN AMERICA AFTER TCJA

\begin{abstract}
Since the 1990s, the US tax treaty network has expanded to include most large developing countries. However, there remains a glaring exception: The US only has two tax treaties in Latin America (Mexico and Venezuela), and one pending tax treaty (Chile). The traditional explanation for why the US has no treaty with, for example, Argentina or Brazil is the US refusal since 1957 to grant tax sparing credits to developing countries. Before the Tax Cuts and Jobs Act of 2017 (TCJA), this explanation was wrong, because the combination of deferral and cross-crediting meant that tax holidays in a source country would not lead to a shift in revenues to a residence country even without tax sparing. This traditional view needs however to be updated given TCJA. On the one hand, there is now an exemption for direct dividends, so that the traditional rationale for not entering into treaties is gone. On the other hand, GILTI means that deferral is abolished and to the extent the income of a CFC exceeds the GILTI threshold there can in fact be a transfer of revenue to the US. Nevertheless, I believe that Latin American countries should enter into treaties with the US, for three reasons. First, cross-crediting still means that even with GILTI there may not be a revenue shift. Second, there are good reasons to enter into treaties even with a revenue shift, such as attracting FDI and limiting tax evasion. Third, Latin American countries are increasingly capital exporters, and the absence of a treaty hurts their multinationals. Finally, now is an opportunity, because the entire US treaty network needs to be updated to take account of TCJA.
\end{abstract}




\section{The Traditional View.}

Since the 1990s, the US tax treaty network has expanded to include most large developing countries, such as China and India, and many smaller ones, such as Kazakhstan. However, there remains a glaring exception: The US only has two tax treaties in Latin America, both with oil exporting countries (Mexico and Venezuela), and one pending tax treaty (Chile). ${ }^{1}$

The traditional explanation for why the US has no treaty with, for example, Argentina or Brazil is the US refusal since 1957 to grant tax sparing credits to developing countries. In 1957, the US negotiated a tax treaty with Pakistan that included a tax sparing provision, i.e. a credit for taxes that would have been paid to Pakistan but for a tax holiday to attract investment. Stanley Surrey, who was then a Harvard law professor but was later to become the first Assistant Secretary for Tax Policy, testified against the Pakistan treaty. His main argument was that granting tax sparing credits would effectively reduce US tax on US source income, but there are also indications that he was opposed to double non-taxation in general. ${ }^{2}$

The Senate rejected the Pakistan treaty, and ever since then it as been inflexible US policy not to grant tax sparing credits, contrary to the position of many European countries and Japan, who view these credits as a tool in helping development. The OECD came out with a paper critical of tax sparing in $1998 .^{3}$ The US occasionally promises a treaty partner (e.g., Israel) that if it ever granted tax sparing to anyone it will extend the policy to that partner, but it does so in the knowledge that it is very unlikely to have to fulfill this promise.

The lack of tax sparing is the traditional reason given by Latin American countries such as Argentina and Brazil for not entering into tax treaties with the US. The argument is that in the absence of tax sparing, tax incentives granted to US multinationals (MNEs) would result in a transfer of revenue from the host country to the US, without any benefit to the US MNE. ${ }^{4}$

\section{Why the Traditional View was Wrong.}

\footnotetext{
${ }^{1}$ All seven US tax treaties signed since 2010 have not been ratified for unrelated political reasons, and now that TCJA is the law, they need to be renegotiated, as explained below.

${ }^{2}$ Surrey, Stanley S., The Pakistan Tax Treaty and “Tax Sparing," 11 NAT'L TAX J. 156, 157 (1958)

${ }^{3}$ OECD, Tax Sparing, A Reconsideration (February, 24 1998), available: https://www.oecd-ilibrary.org/taxation/tax-sparing_9789264162433-en

${ }^{4}$ Avi-Yonah, Reuven S., Double Tax Treaties: An Introduction (December 3, 2007).
} 
This traditional narrative was wrong before TCJA, for two reasons. First, before 2017, US MNEs generally enjoyed deferral on active income, so that a US MNE with a controlled foreign corporation (CFC) in Argentina or Brazil would not pay current US tax on its earnings even if there was no host country tax. Second, pre-TCJA law allowed for cross-crediting, so that to the extent the US MNE had high tax active foreign source income anywhere, it could average the foreign tax rate with a zero tax in a host country. Cross-crediting created an incentive to invest in a host country that grants a tax holiday for any US MNE in an excess credit position (i.e., with foreign taxes that exceed the US tax rate). ${ }^{5}$

Thus, I believe that before TCJA, tax sparing was a red herring, and not the real reason for the lack of US tax treaties with Latin America. The real reason was presumably uneven investment flows that meant that there would be one-sided revenue losses for the host country. It is no accident that the only two treaties in force are with Mexico and Venezuela, two oil exporting countries with more even investment flows with the US.

\section{TCJA: Exemption.}

This analysis is now obsolete, because the TCJA has changed the background US rules. The first major change is the adoption of a partial participation exemption. Under TCJA, to the extent a CFC of a US MNE earns active income that is below a deemed $10 \%$ return on its basis in tangible assets, there is no US tax imposed not just when the income is earned, but also when it is repatriated to the US as a dividend.

This provision is better than tax sparing, because tax sparing as a foreign tax credit is limited to the US tax rate (currently 21\%). Instead, if a US MNE now builds a factory in Argentina or Brazil and earns a return up to $10 \%$ of its basis, and the factory enjoys a tax holiday, then the income is exempt from US tax even when repatriated, regardless of what the pre-tax holiday host country tax rate was. ${ }^{6}$

This provision clearly acts as an incentive for US MNEs to shift actual production facilities in response to tax holidays abroad. However, for reasons set out below, the incentive would be increased if there were a tax treaty in place. Since the tax sparing argument no longer applies, the exemption should encourage negotiation of tax treaties between the US and Latin America.

\section{TCJA: GILTI and Cross Crediting.}

\footnotetext{
${ }^{5}$ Avi-Yonah, Reuven S., Making Sense of U.S. International Taxation: Six Steps toward Simplification. Bull. for Int'l Fiscal Documentation 55, no. 9 (2001): 493-7.

${ }^{6}$ Avi-Yonah, Reuven S., Guilty as Charged: Reflections on TRA 17 (November 25, 2017). Tax Notes, Vol. 157, No. 8, November 2017.
} 
If the return on the foreign investment exceeds $10 \%$ of the basis in tangible assets, then the investment is subject to current US tax under the global intangible lowtaxed income (GILTI) provision. ${ }^{7}$ Since most US MNEs rely heavily on intangibles, GILTI limits the scope of the participation exemption. And since GILTI eliminates deferral, then old tax sparing argument becomes more valid: If there are no other sources of foreign income and GILTI applies, then an investment that benefits from tax sparing would be subject to US tax at $10.5 \%$, so that the value of the tax holiday is diminished (but not eliminated if the foreign tax rate absent the tax holiday exceeds 10.5\%).

However, there is another important provision in TCJA: GILTI allows a foreign tax credit up to $80 \%$ of the foreign tax (i.e., an effective foreign tax rate of $13.125 \%$ eliminates GILTI), and moreover allows for cross crediting. ${ }^{8}$ Given that the US tax rate was cut from $35 \%$ to $21 \%$, there are a lot of US MNEs in an excess credit position. In that case a tax holiday would still be helpful because of cross-crediting, as the following example shows:

1. Assume a US MNE with no tangible assets and foreign income earned by a CFC in a country with a $25 \%$ tax rate:

Foreign income 100

Foreign tax 25

GILTI tax $\quad 10.5$

FTC 20 (limited to $80 \%$ of foreign tax)

FTC limit $\quad 10.5$ (US tax rate $x$ foreign source income)

US tax 0

Excess credits 9.5 (lost, because no carryover)

Effective tax rate $25 \%$

2. Now assume the same MNE can earn an additional 100 in a foreign country with a tax holiday:

Foreign income 200

Foreign tax 25

GILTI tax $\quad 21$

FTC 20

FTC limit $\quad 21$

US tax 1

Excess limit $\quad 1$

Effective tax rate $13 \%$

\footnotetext{
${ }^{7}$ Section 951A, as enacted under P.L. 115-97 (the Tax Cuts and Jobs Act, or TCJA).

${ }^{8}$ Avi-Yonah, Reuven S., The International Provisions of the TCJA: A Preliminary

Summary and Assessment (December 23, 2017).
} 
Thus, the investment in the tax holiday country reduced the effective overall tax rate and eliminated the excess credits (which cannot be used given that there are no carryforwards under GILTI). This means that even under TCJA the tax holiday remains effective, and the tax sparing argument remains specious.

\section{Conclusion: Why Should Latin American Countries Enter into Tax Treaties with the US after TCJA?}

There are three good reasons that Latin American countries should consider entering into tax treaties with the US after TCJA.

First, as we have seen, to the extent that the participation exemption applies, the result is better than tax sparing for countries that offer tax holidays. To the extent GILTI applies, there is still an incentive to invest in a tax holiday country because of cross-crediting, so that even with GILTI there may not be a revenue shift. Many US MNEs are now in an excess credit position because of the tax rate cut.

Second, there are good reasons to enter into treaties even with a revenue shift, such as attracting FDI and limiting tax evasion. There is an abundant empirical literature that shows that tax treaties encourage FDI, primarily because they serve an insurance function against sudden tax increases and provide for a mechanism to settle disputes. In addition, tax treaties limit capital flight and tax evasion because of exchange of information; absent a tax treaty the US becomes a tax haven for rich Latin Americans.

Third, Latin American countries are increasingly capital exporters, and the absence of a treaty hurts their multinationals. Argentina and Brazil in particular are now home to many MNEs, and in the absence of a treaty, dividends from their US subsidiaries are subject to a hefty $30 \%$ withholding tax. Treaty shopping has become more difficult because of limitation on benefits (LOB) provisions as well as the new primary purpose test, which applies to Latin American treaties with countries like the Netherlands or Belgium that have traditionally served as conduits for their FDI into the US.

Finally, now is an opportunity, because the entire US treaty network needs to be updated to take account of TCJA. Under the US treaty override rule, TCJA overrides earlier treaties, and it includes provisions like the BEAT that arguably violate treaties. Treaties that have not been ratified, like the Chile treaty, now need to be renegotiated because otherwise they will override TCJA. The US would presumably be happy to negotiate new treaties with other Latin American countries as well, and the actual withholding tax rates are negotiable, so that any revenue loss can be limited. There is no reason why China or India should have a tax treaty with the US, while Argentina or Brazil do not have one. 